\title{
Protection of Grapevine Pruning Wounds against Eutypa lata by Biological and Chemical Methods
}

\author{
F. Halleen ${ }^{1 *}$, P.H. Fourie ${ }^{2}$, P.J. Lombard ${ }^{3}$
}

(1) ARC Infruitec-Nietvoorbij (The Fruit, Vine and Wine Institute of the Agricultural Research Council), Private Bag X5026, Stellenbosch 7599, South Africa

(2) Citrus Research International, P.O. Box 2201, Stellenbosch 7602, South Africa

(3) Kelp Products (Pty) Ltd, PO Box 325, Simonstown, 7995

Date submitted for publication: March 2010

Date accepted for publication: September 2010

Key words: Bacillus subtilis, benomyl, flusilazole, Trichoderma, Vitis vinifera

\begin{abstract}
Eutypa dieback, caused by the fungus Eutypa lata, is a serious disease of grapevines that infects mainly through pruning wounds. The aim of this study was to evaluate the in vitro efficacy of fungicides from various chemical groups against E. lata, as well as the in vivo efficacy of the most effective fungicides and selected bacterial and fungal antagonists of $E$. lata, in grapevine pruning wound protection trials. In vitro studies revealed that flusilazole, tebuconazole, benomyl, fenarimol and myclobutanil were the most effective fungicides to inhibit mycelial growth of $E$. lata. Two field trials were conducted, one subjected to artificial inoculation and the second to natural infection only. In the first, benomyl, flusilazole and commercially available Trichoderma harzianum-containing products and an experimental Bacillus subtilis strain were applied to fresh pruning wounds. Two Cabernet Sauvignon vineyards were pruned in August 2001 and 2002 and immediately treated and inoculated with a spore suspension of $\boldsymbol{E}$. lata one day later. Isolations were made from the treated pruning wounds after 12 months to assess the effectiveness of the treatments. The fungicides benomyl and flusilazole were the most effective treatments, although the Trichoderma treatments T77 and Trichoseal spray caused a significant reduction in $E$. lata infection. In a second trial, pruning wounds of Cabernet Sauvignon, Sauvignon blanc, Red Globe and Bonheur were treated with the Trichoderma products Vinevax (= Trichoseal spray) and Eco77 (= T77) in August 2005 and 2006, subjected to natural infection only and evaluated after seven months. Vinevax and Eco77 not only reduced $E$. lata, but they also reduced the incidence of other grapevine trunk disease pathogens.
\end{abstract}

\section{INTRODUCTION}

Eutypa dieback, caused by the fungus Eutypa lata, is a serious disease of grapevine (Vitis vinifera L.) in South Africa, as well as in most other grape-producing areas of the world (Carter, 1994). The disease severely reduces the productive lifespan of a vineyard, and this is reflected not only in the loss of yield, but also in the cost of reworking, removing and replanting such a vineyard (Munkvold et al., 1994; Wicks \& Davies, 1999; Van Niekerk et al., 2003). Eutypa lata is commonly associated with symptoms like stunted, zigzag shoot growth and dieback of arms or even entire vines. Although symptom expression differs considerably between cultivars, leaves on the affected shoots are small and usually yellow, cupped, tattered, speckled, and often dead around the margins (Carter, 1994). Flower clusters on stunted shoots are normal, but shrivel and die on severely affected shoots. Bunches that appear normal at the beginning of the season may also shrivel and die (Creaser \& Wicks, 2000). Yield reduction is primarily due to a diminished number of clusters per vine (Munkvold et al., 1994). Reduced wine quality may also occur due to uneven berry maturity on infected vines (Wicks \& Davies, 1999).

Infection occurs when ascospores of the fungus enter pruning wounds (Moller \& Kasimatis, 1978). Ascospores are released from perithecia one or two hours after the onset of as little as 2 mm of rain (Pearson, 1980; Trese et al., 1980). This release will continue as long as it rains, but a period of depletion, a so-called "exhaustion phenomenon", might occur after prolonged release (Petzoldt et al., 1983). The ascospores germinate and grow into the wood below the wound, eventually causing progressive dieback symptoms of the plant. Various studies have investigated the susceptibility of pruning wounds to Eutypa infections, and it is generally accepted that susceptibility is dependent on the time of pruning and the age of the pruning wound. Pruning wounds made early in the dormant season are much more susceptible and stay susceptible for much longer periods than pruning wounds made during the mid- and late dormancy periods (Petzoldt et al., 1981; Trese et al., 1982; Munkvold \& Marois, 1995; Chapuis et al., 1998; John et al., 2005). The decrease in susceptibility is correlated with an increase in suberin and lignin deposition and with degree-day accumulation (Munkvold \& Marois, 1995). Populations of nonpathogenic microorganisms on wound surfaces are also more active and increase more rapidly during the mid- and late dormancy periods (Munkvold \& Marois, 1995; Chapuis et al., 1998). Some of these microorganisms, which can occur naturally on grapevine pruning wounds, may have the ability to reduce E. lata infections (Ferreira et al., 1991; Munkvold \& Marois, 1993b; Schmidt et al., 2001). Furthermore, sap flow from pruning wounds, which 
often occurs around budbreak, might affect pathogen infections by means of flushing (Munkvold \& Marois, 1995; John et al., 2005). The exudate also contains carbohydrates, amino acids and organic acids that may promote rapid growth of beneficial microflora in pruning wounds, which in turn increase competition with pathogens such as E. lata (Munkvold \& Marois, 1995). Due to these factors, it is recommended that pruning be done later in the dormant season.

Various studies have shown that the age of the wood pruned (i.e. one-, two- or three-year-old wood) does not influence susceptibility (Trese et al., 1980; Petzoldt et al., 1981; Trese et al., 1982; Munkvold \& Marois, 1995). Furthermore, artificial inoculations showed that wound size and relative position of a wound on the vine did not influence infection (Petzoldt et al., 1981). It therefore is clear that all pruning wounds should be protected for an extended period after pruning.

Several field trials have been conducted in the USA to demonstrate the potential of benomyl as a pruning wound protectant against Eutypa infections, either applied as a paint (Moller \& Kasimatis, 1980; Pearson, 1982; Gendloff et al., 1983; Munkvold \& Marois, 1993a), by means of a pneumatic sprayer-pruning shear (Munkvold \& Marois, 1993a) or with an air-blast sprayer (Ramsdell, 1995). Benomyl has been registered in the USA as a paint application at $25 \mathrm{~g} / \mathrm{L}$ for this purpose since 1976. Despite these applications of Benomyl, the incidence of Eutypa dieback was still of great concern in California and questions arose regarding its efficacy (Munkvold \& Marois, 1993a). Munkvold and Marois (1993a) identified flusilazole as a possible alternative to benomyl. The literature regarding the efficacy of these two fungicides varies greatly. Munkvold and Marois (1993a) observed that both fungicides were very effective in field experiments, although flusilazole was the only fungicide that could protect pruning wounds against infection 14 days after treatment. In contrast, Creaser and Wicks (2002) found that benomyl (and certain wound sealants) were the only treatments that could protect pruning wounds against infection 14 days after treatment in Australia. Subsequent trials conducted by Sosnowski et al. (2004) confirmed these results. However, the registration of benomyl has recently been withdrawn in the USA and it is no longer available in most countries. Sosnowski et al. $(2004,2008)$ evaluated carbendazim, another benzimidazole fungicide, and found it to be as effective as benomyl and that it could protect pruning wounds even if the treated wounds were challenged with Eutypa 14 days after application.

Rainfall has a considerable effect on fungicide effectiveness. Munkvold and Marois (1993a) even recommended that a second application be applied if rainfall occurs shortly after fungicide application. The ideal would be a treatment that could be effective regardless of environmental conditions. Biological control agents that colonise pruning wounds and render prolonged protection despite environmental factors would therefore be of great benefit. Furthermore, environmental protection has also come to the fore in recent years, increasing the demand for biological control agents. Ferreira et al. (1991) found a Bacillus subtilis isolate that strongly inhibited E. lata. However, despite its efficacy in field trials, the isolate was never commercialised due to the lack of market interest at the time. Promising results were also obtained with Fusarium lateritium (Munkvold \& Marois, 1993b; John et al., 2005), as well as Cladosporium herbarum (Munkvold \& Marois, 1993b). McMahan et al. (2001) conducted bioassays with a benomyl-resistant Fusarium lateritium strain obtained through UV mutagenesis, and suggested that it could be applied in combination with benomyl at $1000 \mu \mathrm{g} / \mathrm{mL}$.

Trichoderma-based products are registered in New Zealand for protection against Eutypa infections (Hunt, 1999). The so-called Trichoprotection $^{\circledR}$ range includes Trichodowels ${ }^{\mathrm{TM}}$, Trichojet ${ }^{\mathrm{TM}}$, Trichoseal $^{\mathrm{TM}}$, Trichoseal-Spray ${ }^{\mathrm{TM}}$ and Vinevax ${ }^{\mathrm{TM}}$, comprising several T. harzianum and T. atro-viride strains. Creaser and Wicks (2002) could not prevent E. lata infections with TrichosealSpray $^{\mathrm{TM}}$. However, this study was only conducted during one season and very low levels of Eutypa infection were obtained through inoculations. Subsequent studies conducted over three seasons on three cultivars with Trichoseal-Spray ${ }^{\mathrm{TM}}$ and Vinevax ${ }^{\mathrm{TM}}$, a replacement product with an identical base formulation, recorded significant reductions in Eutypa infections (John et al., 2005). Volatile and non-volatile metabolites produced by $T$. harzianum strains AG1, AG2 and AG3, three of the components of the Trichoprotection ${ }^{\circledR}$ range, reduced the growth of E. lata in vitro (John et al., 2004). Co-inoculation of E. lata and T. harzianum strain AG1 in grapevine wood resulted in changes to the integrity of E. lata hyphae, including abnormal swellings and collapsed and shrivelled hyphae. Parallel growth and coiling were also observed, which might indicate mycoparasitic activity (John et al., 2005). John et al. (2008) also demonstrated that T. harzianum colonised and persisted in grapevine wood for 20 months and that it had the potential to protect vines from infection by E. lata.

Boric acid, formulated as Biopaste (5\% boric acid) and Bioshield ( $5 \%$ boric acid formulated in a spore suspension of C. herbarum), has been tested in California as a possible replacement for benomyl. Although both products significantly reduced Eutypa infections, bud failure located at the first node below the pruning wound was associated with these treatments (Rolshausen \& Gubler, 2005). Formulations of boric acid must therefore be optimised before they can be recommended as safe alternatives.

Despite Eutypa being a disease of major economic importance in the Western Cape Province of South Africa (Halleen et al., 2001), most producers do not apply any form of pruning-wound protection. This lack of protection is furthermore compounded by the fact that no fungicide is registered for the control of this disease in local vineyards (Nel et al., 2003) and no fungicide has ever been tested for the protection of pruning wounds under vineyard conditions. Moreover, at the onset of this study, several Trichoderma products were marketed as grapevine pruning wound protectants, but these products were not registered and nor has their efficacy been determined under local conditions. The aim of this study was therefore to evaluate the in vitro efficacy of fungicides from various chemical groups against $E$. lata, as well as the in vivo efficacy of the most effective fungicides, Bacillus subtilis (Ferreira et al., 1991) and selected Trichoderma products, in grapevine pruning wound protection trials on grapevines subjected to artificial inoculation, as well as natural infection.

\section{MATERIALS AND METHODS}

\section{In vitro evaluation of fungicides}

Twelve fungicides were screened in vitro for mycelial inhibition of 12 E. lata isolates according to the method of Munkvold and 
Marois (1993a). The fungicides were benomyl (Benlate 500 WP; Dow Agrosciences Southern Africa PTY, Silverton, South Africa), flusilazole (Olymp 100 EW; Du Pont, Halfway House, South Africa), myclobutanil (Systhane 20 EW; Dow Agrosciences Southern Africa PTY), tebuconazole (Folicur 250 EW; Bayer Cropscience, Isando, South Africa), fenarimol (Rubigan 12\% EC; Dow Agrosciences Southern Africa PTY), trifloxystrobin (Flint 50 WG; Bayer Cropscience), kresoxim-methyl (Stroby WG 500 g/kg; BASF South Africa PTY, Halfway House, South Africa), azoxystrobin (Quadris 50 WG; Syngenta, Halfway House, South Africa), spiroxamine (Prosper 500 EC; Bayer Cropscience), fenhexamid (Teldor $500 \mathrm{SC}$; Bayer Cropscience), mancozeb (Penncozeb WG $750 \mathrm{~g} / \mathrm{kg}$; BASF South Africa PTY) and pyrimethanil (Scala SC $400 \mathrm{~g} / \mathrm{L}$; Bayer Cropscience).

The E. lata isolates were obtained from perithecia found on diseased vines originating from vineyards in the Stellenbosch, Durbanville, Somerset West, Paarl and Wellington areas of the Western Cape Province, South Africa. Isolates were stored on potato-dextrose agar (PDA, Biolab, Midrand, Johannesburg) slants at $4^{\circ} \mathrm{C}$ in the culture collection at ARC Infruitec-Nietvoorbij (Stellenbosch, South Africa) and transferred to PDA in Petri dishes for propagation when needed. The Petri dishes were subsequently incubated at $23^{\circ} \mathrm{C}$ for one week, at which time there was sufficient growth to transfer it to fungicide-amended media. The fungicides were suspended in sterile distilled water and added to molten $( \pm$ $50^{\circ} \mathrm{C}$ ) PDA in sufficient quantities to achieve final concentrations of $0,0.01,0.05,0.1,0.5,1.0,5.0$ and $10.0 \mu \mathrm{g} / \mathrm{mL}$. Mycelium plugs ( $4 \mathrm{~mm}$ in diameter), obtained from the margins of actively growing cultures, were transferred to fungicide-amended plates. Three mycelium plugs (three different isolates) were placed equidistant from each other on each plate. There were three replicates of each fungicide concentration, and the experiment was repeated. Concentrations of 50.0 and $100.0 \mu \mathrm{g} / \mathrm{ml}$ were added for the less effective fungicides when the experiment was repeated. The dishes were incubated for five days at $23^{\circ} \mathrm{C}(12 \mathrm{~h}$ light per day), after which the diameter of each colony was measured twice perpendicularly.

The experimental design was completely randomised with a $12 \times 12 \times 8$ factorial and three random replications. The factors were 12 isolates, 12 fungicides and eight concentrations. The percentage inhibition was calculated as follows: $100 \times[$ (colony diameter on fungicide-amended plate $-4 \mathrm{~mm}$ ) - (colony diameter of the control $-4 \mathrm{~mm})] /($ colony diameter on fungicide-amended plate $-4 \mathrm{~mm}$ ). The percentage inhibition data of both experiments was pooled and linear regressions were fitted to concentrations for each isolate and fungicide separately, after the extreme tail points had been deleted. The equations fitted were as follows: percentage inhibition $=\mathrm{a}+\mathrm{bx}(\mathrm{a}=$ intercept, $\mathrm{b}=$ slope and $\mathrm{x}=$ fungicide concentration). The concentration at which mycelial growth was inhibited by $50 \%\left(\mathrm{EC}_{50}\right.$ value $)$ was calculated as follows: $\mathrm{EC}_{50}$ $=\mathrm{b} /(50-\mathrm{a})$. The $\mathrm{EC}_{50}$ values and the rate of change (slopes) were subjected to analysis of variance and Student's t-LSD (least significant difference) was calculated at a 5\% significance level to compare fungicide means (SAS, 1990). The Shapiro-Wilk test was performed to test normality on residuals (Shapiro \& Wilk, 1965). Outliers were discarded until the residuals were normally distributed.

\section{Field experiments}

\section{Trial one}

Two Cabernet Sauvignon vineyards, located in the Durbanville and Stellenbosch areas respectively, were identified for the field experiment. The incidence of Eutypa dieback is relatively high in both these areas due to environmental conditions favouring disease development (Halleen et al., 2001). The vineyards were eight and 10 years old at the time of the first season's experiment.

The fungicides benomyl and flusilazole proved to be the most effective fungicides in the in vitro evaluation and were included in the field experiments. The fungicides were applied at $12500 \mu \mathrm{g}$ active ingredient $/ \mathrm{mL}$ according to Munkvold and Marois (1993a). Several potential biological control agents/ products were also included. Isolates of $B$. subtilis (Isolate EE, ARC Infruitec-Nietvoorbij, South Africa; Ferreira et al., 1991) and T. harzianum (Isolate T77; ARC Infruitec-Nietvoorbij, South Africa - subsequently registered as Eco77, Plant Health Products PTY Ltd., Nottingham Road, South Africa), which previously were proven to be antagonistic to E. lata, were included. T77 was applied with $(+)$ and without (-) 1\% Bio-Stabiliser (AgroOrganics, Strand, South Africa) to investigate the potential benefits of Bio-Stabiliser, a sticker. Bacillus subtilis (with 1\% peptone and 1\% sucrose; Ferreira et al., 1991) and T77 were applied at $10^{8}$ and $10^{6} \mathrm{spores} / \mathrm{mL}$ respectively. Two commercially available products containing T. harzianum, namely TrichosealSpray (Agrimm Technologies Ltd, New Zealand) and Bio-Tricho (Agro-Organics, Strand, South Africa), were also included. These products were applied according to manufacturer's specifications (Trichoseal-Spray at $10 \mathrm{~g} / \mathrm{L}$; Bio-Tricho at $4 \mathrm{~g} / \mathrm{L}$ ).

Both vineyards were pruned in August 2001 and 2002 (two buds/spur). Fresh pruning wounds were spray-treated with chemical and biological control agents immediately after pruning by means of ordinary household hand-held trigger spray canisters (Munkvold \& Marois, 1993a). Ten plants were used for each treatment and five pruning wounds were treated on each plant. The control plants were treated with distilled water only (inoculated control). Treated pruning wounds were inoculated with $1000 \mathrm{E}$. lata ascospores in a $50-\mu \mathrm{L}$ droplet of sterile distilled water 24 hours after the treatments had been applied to fresh wounds. An uninoculated control treatment was also included to determine the levels of natural infection. The trial design was a randomised block design.

The efficacy of treatments to prevent E. lata infection was determined by making isolations from each of the treated pruning wounds 12 months after treatment (Munkvold \& Marois, 1993a). Spurs were removed in the vineyard by means of hand pruning shears and immediately taken to the laboratory for surface sterilisation ( $30 \mathrm{~s}$ in $70 \%$ ethanol, $5 \mathrm{~min}$ in $0.35 \%$ sodium hypochlorite and 30 $\mathrm{s}$ in $70 \%$ ethanol) before isolations were made. Spur sections were split longitudinally to reveal the xylem and pith regions. Twelve pieces of tissue (approximately $1 \times 1 \mathrm{~mm}$ in size) were aseptically removed with a scalpel from the interface between apparently healthy and discoloured xylem tissue in each pruning wound and placed in Petri dishes containing 2\% potato dextrose agar (PDA) and $250 \mathrm{mg} / \mathrm{L}$ chloramphenicol. Dishes were incubated in an incubation growth room at $\pm 23^{\circ} \mathrm{C}$. Fungal and bacterial growth from plated tissue pieces was monitored daily for a period of four weeks. The presence of E. lata and other pruning wound 
invaders (Phaeomoniella chlamydospora, Botryosphaeriaceae and Phomopsis spp.) was noted. Fungal identification was based on colony characteristics and microscopic morphology.

\section{Trial two}

A second trial was conducted with only two biological control agents, Eco77 and Vinevax [Agrimm Technologies Ltd, New Zealand (Vinevax replaced Trichoseal-Spray, but has identical base formulation)]. The treated pruning wounds were not inoculated with E. lata as was the case in trial one.

Four vineyards were selected, namely two wine grape cultivars, Cabernet Sauvignon and Sauvignon blanc located in the Simondium area, and two table grape cultivars, Red Globe and Bonheur located in the Wellington area. The vineyards were five, nine, eight and seven years old respectively, and were visually free of Eutypa symptoms. As the incidence of Eutypa dieback in these areas is normally relatively high, climatic conditions were considered to favour disease development.

The vines were pruned in August 2005 and 2006. The Cabernet Sauvignon and Sauvignon blanc vines were pruned to two buds per cane, while the Red Globe and Bonheur vines were pruned to eight buds per cane. The pruning wounds were treated with the biological control agents immediately after pruning with a hand-held trigger spray canister. The trial consisted of three treatments: Vinevax (10 g/L), Eco77 (0.5 g/L) and a distilled water control with 10 replications per treatment. A replication consisted of a row-unit of four to six plants, depending on the vineyard. Although all the pruning wounds of a row-unit were treated, only two spurs per plant (one on each cordon arm) were used for further evaluation. Only the four middle vines per rowunit were used for further evaluations. Thus each treatment was applied on 80 pruning wounds in each of the four trial vineyards. The trial design was a randomised block design.

Evaluation after seven months was done exactly as described in trial one, by plating eight $1 \times 1 \mathrm{~mm}$ pieces of dissected wood onto PDA in Petri dishes. The incidence of fungi present in each pruning wound was determined as a percentage of the total number of pruning wounds colonised. Complete split-split-plot analyses were performed, with cultivar as the main plot factor, year as subplot factor and treatment as sub-sub-plot factor. Data were subjected to analyses of variance using SAS version 8.1 (SAS, 1990). Student's t-least significant difference values were calculated at the 5\% confidence level to facilitate comparison between the treatment means.

\section{RESULTS}

\section{In vitro evaluation of fungicides}

The growth rates of the 12 isolates were similar and no fungicide $\mathrm{x}$ isolate interaction was observed. Flusilazole, tebuconazole, benomyl, fenarimol and myclobutanil were the most effective fungicides, with $\mathrm{EC}_{50}$ values of $0.005,0.01,0.19,0.29$ and $1.48 \mu \mathrm{g} / \mathrm{mL}$ respectively. The hydroxy-analide fenhexamid, and strobilurin fungicides trifloxystrobin, kresoxim-methyl and azoxystrobin, were the least effective, with $\mathrm{EC}_{50}$ values $>98 \mu \mathrm{g}$ / $\mathrm{mL}$ (Table 1).

Benomyl proved to be the most effective fungicide based on the rate of change in $\mathrm{EC}_{50}$ for a $1 \%$ increase in concentration (178.0\%; Table 1), and would therefore be very effective at

\section{TABLE 1}

Sensitivity of 12 Eutypa lata isolates to different fungicides (in vitro).

\begin{tabular}{lcc}
\hline Fungicide & $\mathbf{E C}_{50}$ value $(\boldsymbol{\mu g} / \mathbf{m L})^{\mathrm{a}}$ & Rate of change $^{\mathrm{b}}$ \\
\hline Flusilazole & $0.01^{\mathrm{a}}$ & $53.97^{\mathrm{b}}$ \\
Tebuconazole & $0.01^{\mathrm{a}}$ & $32.10^{\mathrm{c}}$ \\
Benomyl & $0.19^{\mathrm{a}}$ & $178.0^{\mathrm{a}}$ \\
Fenarimol & $0.29^{\mathrm{a}}$ & $8.72^{\mathrm{de}}$ \\
Myclobutanil & $1.48^{\mathrm{a}}$ & $16.46^{\mathrm{d}}$ \\
Pyrimethanil & $4.54^{\mathrm{b}}$ & $6.59^{\mathrm{de}}$ \\
Spiroxamine & $5.33^{\mathrm{b}}$ & $8.01^{\mathrm{de}}$ \\
Mancozeb & $22.36^{\mathrm{c}}$ & $1.34^{\mathrm{e}}$ \\
Fenhexamid & $98.65^{\mathrm{d}}$ & $0.36^{\mathrm{e}}$ \\
Azoxystrobin & $100.0^{\mathrm{d}}$ & $0.22^{\mathrm{e}}$ \\
Trifloxystrobin & $99.76^{\mathrm{d}}$ & $0.20^{\mathrm{e}}$ \\
Kresoxim-methyl & $100.0^{\mathrm{d}}$ & $0.17^{\mathrm{e}}$ \\
LSD $(P=0.05)$ & $1.482^{\mathrm{a}}$ & 12.940 \\
\hline
\end{tabular}

${ }^{\text {a }}$ Values within each column followed by the same letter do not differ significantly $(P=0.05)$.

${ }^{\mathrm{b}}$ Effective rate of change in $\mathrm{EC}_{50}$ value for a $1 \%$ increase in concentration.

low concentrations. Compared to benomyl, flusilazole and tebuconazole had significantly lower rates of change $(53.97 \%$ and $32.10 \%$ respectively), although these were significantly higher than the other fungicides (rates of change less than 16.46\%).

\section{Field experiments}

\section{Trial one}

Analysis of variance of percentage incidence data of $E$. lata, $P a$. chlamydospora, Botryosphaeriaceae, Phomopsis and Trichoderma spp. isolated from pruning wounds showed no significant season $\times$ treatment interaction $(P>0.05$, ANOVA not shown $)$. Significant effects for treatment were evident for E. lata $(P<$ $0.0001)$, Phomopsis $(P=0.0458)$, Trichoderma $(P<0.0001)$ and Pa. chlamydospora $(P=0.0815)$, but not for Botryosphaeriaceae $(P=0.6026)$. These effects will be discussed, and the incidences of these fungi in pruning wounds as they were affected by the various treatments are summarised in Table 2.

Eutypa lata: E. lata was isolated from $48.5 \%$ of the pruning wounds of the inoculated control treatment (Table 2). The benomyl $(5.0 \%)$ and flusilazole (5.5\%) treatments effected the lowest $E$. lata incidences and, compared to the inoculated control, reduced infection by $89.7 \%$ and $88.7 \%$ respectively. The incidence of Eutypa lata in the Bacillus and Bio-Tricho treatments $(45.5 \%$ and $39.0 \%$ respectively) did not differ significantly from the inoculated control treatment. The T77(+), T77(-) and TrichosealSpray treatments effected significantly lower incidences $(34.0 \%$, $28.5 \%$ and $28.5 \%$ respectively). Natural infection was very low, with E. lata isolated from only $2 \%$ of the pruning wounds on untreated, uninoculated control plants. 


\section{TABLE 2}

Incidence (mean percentage) of the pruning wound invaders Eutypa lata, Botryosphaeriaceae spp., Phaeomoniella chlamydospora, Phomopsis spp. and the biological control agent Trichoderma isolated ${ }^{\mathrm{x}}$ from Cabernet Sauvignon pruning wounds treated with various chemical and biological treatments directly after pruning ${ }^{\mathrm{y}}$ and inoculated with $1000 \mathrm{E}$. lata ascospores one day later (Trial 1).

\begin{tabular}{|c|c|c|c|c|c|}
\hline \multirow[b]{2}{*}{ Treatment } & \multicolumn{5}{|c|}{ Incidence of pruning wound invaders ${ }^{\mathrm{z}}$} \\
\hline & Eutypa lata & $\begin{array}{c}\text { Botryosphaeriaceae } \\
\text { spp. }\end{array}$ & $\begin{array}{l}\text { Phaeomoniella } \\
\text { chlamydospora }\end{array}$ & $\begin{array}{l}\text { Phomopsis } \\
\text { spp. }\end{array}$ & Trichoderma \\
\hline Control (inoculated) & $48.5^{\mathrm{a}}$ & $12.0^{\mathrm{a}}$ & $14.5^{\mathrm{ab}}$ & $29.0^{\text {a }}$ & $0.0^{\mathrm{b}}$ \\
\hline Bacillus subtilis & $45.5^{\mathrm{ab}}$ & $10.0^{\mathrm{a}}$ & $11.0^{\mathrm{ab}}$ & $37.0^{\mathrm{a}}$ & $0.0^{\mathrm{b}}$ \\
\hline Bio-Tricho & $39.0^{a b c}$ & $10.0^{\mathrm{a}}$ & $13.5^{\mathrm{ab}}$ & $27.5^{\mathrm{ab}}$ & $12.0^{\mathrm{b}}$ \\
\hline T77 (+ Bio-Stabiliser) & $34.0^{\mathrm{bc}}$ & $11.5^{\mathrm{a}}$ & $20.0^{\text {a }}$ & $31.0^{\mathrm{a}}$ & $38.0^{\text {a }}$ \\
\hline T77 (- Bio-Stabiliser) & $28.5^{c}$ & $9.0^{\text {a }}$ & $13.5^{\mathrm{ab}}$ & $30.5^{\text {a }}$ & $29.5^{\text {a }}$ \\
\hline Trichoseal-Spray & $28.5^{\mathrm{c}}$ & $11.0^{\mathrm{a}}$ & $12.5^{\mathrm{ab}}$ & $34.0^{a}$ & $45.0^{\mathrm{a}}$ \\
\hline Flusilazole & $5.5^{\mathrm{d}}$ & $9.5^{\text {a }}$ & $4.5^{\mathrm{b}}$ & $17.5^{\mathrm{b}}$ & $0.0^{\mathrm{b}}$ \\
\hline Benomyl & $5.0^{\mathrm{d}}$ & $13.0^{\mathrm{a}}$ & $3.5^{b}$ & $27.0^{a b}$ & $0.0^{\mathrm{b}}$ \\
\hline Control (uninoculated) & $2.0^{\mathrm{d}}$ & $18.5^{\mathrm{a}}$ & $19.5^{\mathrm{a}}$ & $37.5^{\mathrm{a}}$ & $0.0^{\mathrm{b}}$ \\
\hline $\operatorname{LSD}(P=0.05)$ & 12.07 & 9.60 & 11.40 & 11.17 & 15.94 \\
\hline
\end{tabular}

${ }^{\mathrm{x}}$ Isolations made during July/August 2002 and 2003.

y Vineyards hand pruned in August 2001 and 2002.

${ }^{z}$ Values within each column followed by the same letter do not differ significantly $(P=0.05)$.

Botryosphaeriaceae: The mean incidence of Botryosphaeriaceae in the untreated, uninoculated control pruning wounds (i.e. natural infection) was $18.5 \%$ (Table 2). Incidences in the treated wounds were slightly lower $(9.0 \%$ to $13 \%)$, but, as mentioned above, none of the treatments caused a significant effect $(P=0.6026)$.

Phaeomoniellachlamydospora:Pa.chlamydospora was isolated from a mean of $19.5 \%$ of the untreated, uninoculated control pruning wounds. Incidences in the pruning wounds treated with benomyl and flusilazole (3.5\% and 4.5\% respectively; Table 2 ) were significantly lower compared to the untreated, uninoculated control.

Phomopsis spp.: Phomopsis spp. were commonly isolated from untreated, uninoculated control plants (37.5\%; Table 2), and flusilazole was the only treatment that brought about statistically lower incidences (17.5\%).

Trichoderma spp.: Trichoderma spp. were only isolated from plants treated with Trichoderma products (Table 2), and incidences were highest in pruning wounds treated with Trichoseal-Spray, T77(+) and T77(-) $(45.0 \%, 38.0 \%$ and $29.5 \%$ respectively). The incidence of Trichoderma was significantly lower in wounds treated with Bio-Tricho (12.0\%).

\section{Trial two}

\section{Incidence of Trichoderma in pruning wounds}

According to the analysis of variance for the effect of treatment, cultivar and season on the percentage incidence of Trichoderma, a three-factor interaction occurred (Cultivar $\times$ Year $\times$ Treatment, $P=0.018$, ANOVA not shown). A further analysis was done with the cultivars and seasons separate. From this analysis, clear differences between treatments were observed for all the cultivars and in both seasons ( $P \leq 0.0001$, ANOVA not shown).
There was a large difference in the incidence of Trichoderma in the pruning wounds (Table 3). The incidence of Trichoderma was quite high in pruning wounds that were treated with Trichoderma-based products (20-76\%), while no Trichoderma occurred in the control plants, except in the Cabernet Sauvignon vineyard during the 2005/2006 season, when it occurred in three pruning wounds. During the 2005/2006 season, the incidence of Trichoderma was significantly higher in the Vinevax treatments, except in Red Globe, where the incidences were similar. The incidence of Trichoderma in the Vinevax and Eco 77 treatments was similar during the 2006/2007 season, except for Red Globe, where Trichoderma occurred significantly more in the Vinevax treatments (Table 3).

\section{Incidence of pathogens in pruning wounds}

The incidence of the most important pruning wound pathogens (E. lata, Botryosphaeriaceae spp., Pa. chlamydospora, Phomopsis spp. and Phaeoacremonium spp.) was determined and calculated as a "total pathogen count". Analysis of variance for the effect of treatment, cultivar and season on the percentage incidence of E. lata, Pa. chlamydospora, Phaeoacremonium spp., Botryosphaeriaceae, Phomopsis and total pathogens isolated from pruning wounds showed no significant Cultivar $\times$ Year $\times$ Treatment interactions ( $P>0.05$, ANOVA not shown), except for E. lata $(P=0.0446)$. Significant effects for treatment were evident for Phaeoacremonium spp. $(P=0.0233$, ANOVA not shown $)$ and total pathogens $(P=0.0488)$, but not for $P a$. chlamydospora $(P$ $=0.7055)$, Botryosphaeriaceae $(P=0.2141)$ and Phomopsis $(P$ $=0.2150)$. These effects will be discussed and the incidences of these fungi in the pruning wounds as they were affected by the various treatments are summarised in Tables 4 and 5 . 


\section{TABLE 3}

Mean incidence of Trichoderma spp. isolated ${ }^{x}$ from pruning wounds treated with Vinevax and Eco77 directly after pruning ${ }^{\mathrm{y}}$ (Trial 2)

\begin{tabular}{|c|c|c|c|}
\hline \multirow{2}{*}{ Cultivar } & \multirow{2}{*}{ Treatment } & \multicolumn{2}{|c|}{ Trichoderma incidence $(\%)^{2}$} \\
\hline & & 2005-2006 & 2006-2007 \\
\hline \multirow{4}{*}{ Sauvignon blanc } & Control & $0.0^{\mathrm{c}}$ & $0.0^{\mathrm{b}}$ \\
\hline & Vinevax & $67.5^{\mathrm{a}}$ & $56.3^{\mathrm{a}}$ \\
\hline & Eco77 & $38.8^{\mathrm{b}}$ & $48.8^{\mathrm{a}}$ \\
\hline & $\operatorname{LSD}(P=0.05)$ & 12.32 & 18.63 \\
\hline \multirow[t]{4}{*}{ Cabernet Sauvignon } & Control & $5.0^{\mathrm{c}}$ & $0.0^{\mathrm{b}}$ \\
\hline & Vinevax & $76.3^{\mathrm{a}}$ & $63.8^{\mathrm{a}}$ \\
\hline & Eco77 & $47.5^{\mathrm{b}}$ & $68.8^{\mathrm{a}}$ \\
\hline & $\operatorname{LSD}(P=0.05)$ & 19.35 & 10.08 \\
\hline \multirow[t]{4}{*}{ Bonheur } & Control & $0.0^{\mathrm{c}}$ & $0.0^{\mathrm{b}}$ \\
\hline & Vinevax & $70.0^{\mathrm{a}}$ & $45.0^{\mathrm{a}}$ \\
\hline & Eco77 & $25.0^{\mathrm{b}}$ & $37.5^{\mathrm{a}}$ \\
\hline & $\operatorname{LSD}(P=0.05)$ & 14.89 & 14.89 \\
\hline \multirow[t]{4}{*}{ Red Globe } & Control & $0.0^{\mathrm{b}}$ & $0.0^{\mathrm{c}}$ \\
\hline & Vinevax & $41.3^{\mathrm{a}}$ & $32.5^{\mathrm{a}}$ \\
\hline & Eco77 & $37.5^{\mathrm{a}}$ & $20.0^{\mathrm{b}}$ \\
\hline & $\operatorname{LSD}(P=0.05)$ & 17.23 & 12.26 \\
\hline
\end{tabular}

x Isolations April 2006 and 2007.

y Pruning 29 Augustus 2005 and 15 August to 1 September 2006.

${ }^{z}$ For each cultivar, values within each column followed by the same letter do not differ significantly $(P=0.05)$.

Eutypa lata: The analysis of cultivars and seasons separately did not reveal any differences between treatments for any of the cultivars during both seasons, except for Red Globe during the $2006 / 2007$ season $(P=0.0813$, ANOVA not shown), where Vinevax caused a significant reduction (Table 4). Eco77 also reduced Eutypa in Red Globe (1.3\%), although it did not differ significantly from the control (11.3\%).

Botryosphaeriaceae: The mean incidence in the untreated, control pruning wounds was $9.4 \%$ (Table 5), but none of the treatments caused a significant reduction.

Phaeomoniella chlamydospora: The mean incidence in the untreated control pruning wounds was $8.9 \%$ (Table 5), but none of the treatments caused a significant reduction.

Phaeoacremonium spp.: Despite the relatively low incidence $(0.8 \%$, Table 5$)$ in the untreated control pruning wounds, both treatments caused a significant reduction compared to the untreated control.

Phomopsis spp.: The mean incidence in the untreated control pruning wounds was $8.1 \%$ (Table 5), but none of the treatments caused a significant reduction.

Total pathogens: The mean total pathogen incidence in the untreated, control pruning wounds was $24.8 \%$ (Table 5). Eco 77
TABLE 4

Mean incidence of the pruning wound invader Eutypa lata isolated $^{\mathrm{x}}$ from pruning wounds treated with Vinevax and Eco77 directly after pruning ${ }^{y}$ (Trial 2).

\begin{tabular}{|c|c|c|c|}
\hline \multirow{2}{*}{ Cultivar } & \multirow{2}{*}{ Treatment } & \multicolumn{2}{|c|}{ Eutypa lata incidence $(\%)^{2}$} \\
\hline & & 2005-2006 & 2006-2007 \\
\hline \multirow[t]{4}{*}{ Sauvignon blanc } & Control & $0.0^{\mathrm{a}}$ & $2.5^{\mathrm{a}}$ \\
\hline & Vinevax & $0.0^{\mathrm{a}}$ & $0.0^{\mathrm{a}}$ \\
\hline & Eco77 & $1.3^{\mathrm{a}}$ & $0.0^{\mathrm{a}}$ \\
\hline & $\operatorname{LSD}(P=0.05)$ & 2.14 & 2.86 \\
\hline \multirow[t]{4}{*}{ Cabernet Sauvignon } & Control & $0.0^{\mathrm{a}}$ & $0.0^{\mathrm{a}}$ \\
\hline & Vinevax & $0.0^{\mathrm{a}}$ & $1.3^{\mathrm{a}}$ \\
\hline & Eco77 & $0.0^{\mathrm{a}}$ & $1.3^{\mathrm{a}}$ \\
\hline & $\operatorname{LSD}(P=0.05)$ & 0.0 & 3.12 \\
\hline \multirow[t]{4}{*}{ Bonheur } & Control & $0.0^{\mathrm{a}}$ & $1.3^{\mathrm{a}}$ \\
\hline & Vinevax & $0.0^{\mathrm{a}}$ & $0.0^{\mathrm{a}}$ \\
\hline & Eco77 & $0.0^{\mathrm{a}}$ & $0.0^{\mathrm{a}}$ \\
\hline & $\operatorname{LSD}(P=0.05)$ & 0.0 & 2.14 \\
\hline \multirow[t]{4}{*}{ Red Globe } & Control & $0.0^{\mathrm{a}}$ & $11.3^{\mathrm{a}}$ \\
\hline & Vinevax & $0.0^{\mathrm{a}}$ & $0.0^{\mathrm{b}}$ \\
\hline & Eco77 & $0.0^{\mathrm{a}}$ & $1.3^{\mathrm{ab}}$ \\
\hline & $\operatorname{LSD}(P=0.05)$ & 0.0 & 10.77 \\
\hline
\end{tabular}

x Isolations April 2006 and 2007.

y Pruning 29 Augustus 2005 and 15 August - 1 September 2006.

${ }^{z}$ For each cultivar, values within each column followed by the same letter do not differ significantly $(P=0.05)$.

was the only treatment that differed from the untreated control and reduced infection by $30 \%$.

\section{DISCUSSION}

One of the objectives of this study was to compare the efficacy of benomyl with newer fungicides with different modes of action. However, the in vitro results clearly emphasise the efficacy of benomyl. Furthermore, resistance to benomyl was not detected in this study, despite the fact that it had been applied to pruning wounds for several years in at least one of the vineyards from which isolates were obtained. Except for the sterol demethylation inhibitor (DMI) fungicides, none of fungicides from the newer chemical classes showed any promise in vitro. It was therefore decided to include flusilazole in the field evaluations. Benomyl is still registered in South Africa for the control of botrytis (Botrytis cinerea) and powdery mildew (Erysiphe necator), whilst flusilazole is registered for the control of powdery mildew (Nel et al., 2003). However, benomyl has recently been withdrawn from the world market and flusilazole is not registered as a pruning wound protectant in South Africa. In recent years, the big question regarding the long-term efficacy of chemical products, especially during extended periods of rainfall, has also come to the fore. Kotze (2008) showed that the inoculation of benomyl- 
TABLE 5

Mean incidence of the pruning wound pathogens Botryosphaeriaceae spp., Phaeomoniella chlamydospora, Phaeoacremonium spp., Phomopsis spp. and total pathogen isolated ${ }^{\mathrm{x}}$ from pruning wounds treated with Vinevax and Eco 77 directly after pruning ${ }^{\mathrm{y}}$ (Trial 2).

\begin{tabular}{|c|c|c|c|c|c|}
\hline \multirow[b]{2}{*}{ Treatment } & \multicolumn{5}{|c|}{ Incidence of pruning wound invaders ${ }^{\mathrm{z}}$} \\
\hline & $\begin{array}{c}\text { Botryosphaeriaceae } \\
\text { spp. }\end{array}$ & $\begin{array}{l}\text { Phaeomoniella } \\
\text { chlamydospora }\end{array}$ & $\begin{array}{l}\text { Phaeoacremonium } \\
\text { spp. }\end{array}$ & Phomopsis spp. & $\begin{array}{c}\text { Total } \\
\text { pathogen }\end{array}$ \\
\hline Control & $9.4^{\mathrm{a}}$ & $8.9^{\mathrm{a}}$ & $0.8^{\mathrm{a}}$ & $8.1^{\mathrm{a}}$ & $24.8^{\mathrm{a}}$ \\
\hline Vinevax & $6.9^{\mathrm{a}}$ & $9.1^{\mathrm{a}}$ & $0.0^{\mathrm{b}}$ & $6.1^{\mathrm{a}}$ & $20.9^{\mathrm{ab}}$ \\
\hline Eco77 & $6.3^{\mathrm{a}}$ & $7.7^{\mathrm{a}}$ & $0.2^{b}$ & $5.0^{\mathrm{a}}$ & $17.3^{\mathrm{b}}$ \\
\hline $\operatorname{LSD}(P=0.05)$ & 3.70 & 3.64 & 0.59 & 3.56 & 5.97 \\
\hline
\end{tabular}

x Isolations April 2006 and 2007.

y Pruning 29 Augustus 2005 and 15 August - 1 September 2006.

${ }^{z}$ Values within each column followed by the same letter do not differ significantly $(P=0.05)$.

treated pruning wounds with Eutypa ascospores seven days after treatment drastically reduced the efficacy of the chemical. As pruning wounds can remain susceptible to infection for long periods (three to four weeks) after pruning (Van Niekerk, 2008), a biological control agent that can colonise pruning wounds and provide long-term protection against infection in spite of climatic conditions would thus be ideal.

The results of the first field trial indicated that the two fungicides benomyl and flusilazole were the most effective treatments against Eutypa. Bacillus subtilis was not effective at all. The reasons for this are not known. Ferreira et al. (1991) applied B. subtilis to wounds on two-year-old canes, inoculated them with an Eutypa spore suspension after four hours and then covered the wounds with aluminium foil, whilst the current trials were conducted on the wounds of one-year-old canes and left open. It is possible that the ascospores were affected by antibiotics produced by the Bacillus. Ferreira et al. (1991) identified at least two antibiotic substances that were responsible for the inhibition of mycelial growth and ascospore germination. In a recent study, Kotze (2008) dual incubated (in vitro) E. lata with the same isolate and showed that $E$. lata displayed little mycelium growth and a clear inhibition zone between the cultures. Malformation of the hyphae, specifically swelling, was observed at a microscopic level. Oneyear-old pruning wounds treated with this Bacillus, challenged with $E$. lata seven days later and evaluated after eight months showed a significant reduction in E. lata incidence $(10.7 \%)$ compared to the inoculated control (37.5\%).

Although the Trichoderma treatments were less effective than the fungicides in the first field trial, T77 and Trichoseal-Spray were able to colonise and survive in pruning wounds and cause significant reduction in E. lata infections. To what extent this colonisation might prevent or inhibit later infections is uncertain at this stage. The addition of Bio-Stabiliser, a sticker, to T77 did not increase Trichoderma's ability to colonise pruning wounds and did not increase the inhibition of Eutypa infections. Colonisation by Bio-Tricho was very low and could explain in part why it was less effective than the other Trichoderma formulations. Mutawila (2010) found a positive correlation between Trichoderma incidence and pathogen reduction. The inoculum dosage could be adjusted in an effort to obtain better colonisation. John et al. (2005) found that Trichoderma harzianum and Fusarium lateritium were much more effective when inoculation with $E$. lata was delayed until 14 days after the wood colonisers were applied, indicating that biocontrol agents might require a period to colonise the wound surface. Similar results were obtained by Munkvold and Marois (1993b) when investigating $F$. lateritium and C. herbarum. The artificially high inoculum doses used in the field evaluations would almost always favour chemicals when compared directly to biological agents. Under natural conditions, in which E. lata infections are much lower (for example $2 \%$ in trial 1 ), biological control agents might be more effective in protecting wounds against pathogen infections.

Various pathogens (E. lata, Botryosphaeriaceae spp., Phomopsis spp. and $P$ a. chlamydospora), all of which are able to infect pruning wounds and eventually cause various trunk diseases, naturally infected plants during the course of this study. Although the primary aim of this study was to protect pruning wounds against E. lata infections, it is clear that control strategies will have to take these pathogens into consideration as well. The efficacy of the various treatments used in this study against Botryosphaeriaceae, Phomopsis and Pa. chlamydospora could not be determined in trial 1 , because additional pruning wounds were not treated and then inoculated with these fungi, as was done in the case of $E$. lata. However, compared to natural infections that occurred in the pruning wounds of the untreated, uninoculated control plants, benomyl and flusilazole reduced $\mathrm{Pa}$. chlamydospora incidence by $82.1 \%$ and $76.9 \%$ respectively, whilst flusilazole reduced Phomopsis incidence by $53.3 \%$.

The second field trial was undertaken to investigate the efficacy of two Trichoderma products subjected to natural infection only. Relying on natural infection is a risk, since infection levels might be extremely low or even absent. Despite these constraints, clear evidence was obtained to show that Trichoderma products were able to significantly reduce pathogens in pruning wounds. However, the results varied between seasons and cultivars. Vinevax was able to reduce Eutypa significantly in Red Globe during the 2006/2007 season, while Eco77 significantly reduced the total pathogen count. However, one might speculate that some of these pathogens, especially Botryosphaeriaceae and Phomopsis, might already be present in the one-year-old cane that is being pruned. Isolation studies investigating the presence of pathogens in newly pruned canes during the 2006/2007 season 
showed that Botryosphaeriaceae and Phomopsis, and to an lesser extent $\mathrm{Pa}$. chlamydospora, were in fact already present in some of the pruned canes, while E. lata did not occur in any of the pruned shoots (results not shown). Finally, this trial again illustrated the ability of Trichoderma to colonise and survive in grapevine pruning wounds.

\section{CONCLUSION}

Pruning wound infections, especially those caused by E. lata, are undoubtedly one of the most important factors that limit the productivity of vineyards in the Western Cape Province. Management strategies, such as strict sanitation practices and the protection of pruning wounds, can be of great benefit to combat this disease.

Producers are urged to apply strict sanitation practices in order to lower inoculum levels. Infected grapevines, or infected parts thereof, should be removed and buried, burnt or composted. The incidence of disease is normally higher in vineyards where perithecia are found (Munkvold et al., 1993). In cases where only part of a plant is removed, it is essential that the wound be treated with a fungicide, biological control agent or wound sealant. Compost made from pruning debris is also a good option, because the composted material can be reintroduced to the vineyard without the fear of re-infection by trunk disease pathogens (Lecomte et al., 2006).

\section{LITERATURE CITED}

Carter, M.V., 1994. Eutypa dieback. In: Pearson, R.C. \& Coheen, A.C. (eds) Compendium of grape diseases. APS Press, Minnesota. pp. 32 - 34.

Chapuis, L., Richard, L. \& Dubos, B., 1998. Variation in susceptibility of grapevine pruning wound to infection by Eutypa lata in south-western France. Plant Pathol. 47, 463-472.

Creaser, M.L. \& Wicks, T.J., 2000. Eutypa dieback - current status and future directions. The Australian Grapegrower and Winemaker. Ann. Tech. Issue 438a, 82-87.

Creaser, M.L. \& Wicks, T.J., 2002. Evaluation of fungicides, paints and a biological product for the prevention of Eutypa dieback of grapevines. The Aust. New Zealand Grapegrower and Winemaker 465, 15-18.

Ferreira, J.H.S., Matthee, F.N. \& Thomas, A.C., 1991. Biological control of Eutypa lata on grapevines by an antagonistic strain of Bacillus subtilis. Phytopathol. 81, 283-287.

Gendloff, E.H., Ramsdell, D.C. \& Burton, C.L., 1983. Fungicidal control of Eutypa armeniacae infecting Concord grapevine in Michigan. Plant Dis. 67, 754-756.

Halleen, F., Volkmann, A.S. \& Fourie, P.H., 2001. Incidence of Eutypa-like symptoms in Cabernet Sauvignon vineyards in the greater Stellenbosch area. Wynboer 143, 12-14.

Hunt, J.S., 1999. Wood-invading fungi: protective management in the vineyard. The Australian Grapegrower and Winemaker. Ann. Tech. Issue 426a, 125-126.

John, S., Scott, E.S., Wicks, T.J. \& Hunt, J.S., 2004. Interactions between Eutypa lata and Trichoderma harzianum. Phytopathologia Mediterranea 43, 95-104.

John, S., Wicks, T.J., Hunt, J.S. \& Scott, E.S., 2008. Colonisation of grapevine wood by Trichoderma harzianum and Eutypa lata. Aust. J. Grape Wine Res. 14, $18-24$.

John, S., Wicks, T.J., Hunt, J.S., Lorimer, M.F., Oakey, H. \& Scott, E.S., 2005. Protection of grapevine wounds from infection by Eutypa lata using Trichoderma harzianum and Fusarium lateritium. Australas. Plant Pathol. 34, 569-575.

Kotze, C., 2008. Biological control of the grapevine trunk disease pathogens: pruning wound protection. MSc. thesis, University of Stellenbosch, Private Bag X1, 7602 Matieland (Stellenbosch), South Africa.

Lecomte, P., Louvet, G., Vacher, B. \& Guilbaud, P., 2006. Survival of fungi associated with grapevine decline in pruned wood after composting. Phytopathologia Mediterranea 45, 127-130.

McMahan, G., Yeh, W., Marshall, M.N., Olsen, M., Sananikone, S., Wu, J.Y.,
Block, D.E. \& VanderGheynst, J.S., 2001. Characterizing the production of a wild-type and benomyl-resistant Fusarium lateritium for biocontrol of Eutypa lata on grapevine. J. Ind. Microbiol. Biotechnol. 26, 151-155.

Moller, W.J. \& Kasimatis, A.N., 1978. Dieback of grapevine caused by Eutypa armeniacae. Plant Dis. Reporter 62, 254-258.

Moller, W.J. \& Kasimatis, A.N., 1980. Protection of grapevine pruning wounds from Eutypa dieback. Plant Dis. 64, 278-280.

Munkvold, G.P. \& Marois, J.J., 1993a. The effects of fungicides on Eutypa lata germination, growth, and infection of grapevines. Plant Dis. 77, 50-55.

Munkvold, G.P. \& Marois, J.J., 1993b. Efficacy of natural epiphytes and colonizers of grapevine pruning wounds for biological control of Eutypa dieback. Phytopathol. 83, 624-629.

Munkvold, G.P. \& Marois, J.J., 1995. Factors associated with variation in susceptibility of grapevine pruning wounds to infection by Eutypa lata. Phytopathol. 85, 249-256.

Munkvold, G.P., Duthie, J.A. \& Marois, J.J., 1993. Spatial patterns of grapevines with Eutypa dieback in vineyards with or without perithecia. Phytopathol. 83, $1440-1448$

Munkvold, G.P., Duthie, J.A. \& Marois, J.J., 1994. Reductions in yield and vegetative growth of grapevines due to Eutypa dieback. Phytopathol. 84, 186192.

Mutawila, C., 2010. Biological control of trunk disease pathogens at the pruning wound site of grapevine. MSc. thesis, University of Stellenbosch, Private Bag X1, 7602 Matieland (Stellenbosch), South Africa.

Nel, A., Krause, M. \& Khelawanlall, N., 2003. A guide for the control of plant diseases. Department of Agriculture, Republic of South Africa.

Pearson, R.C., 1980. Discharge of ascospores of Eutypa armeniacae in New York. Plant Dis. 64, 171-174.

Pearson, R.C., 1982. Protection of grapevine pruning wounds from infection by Eutypa armeniacae in New York State. Am. J. Enol. Vitic. 33, 51-52.

Petzoldt, C.H., Moller, W.J. \& Sall, M.A., 1981. Eutypa dieback of grapevine: seasonal difference in infection and duration of susceptibility of pruning wounds. Phytopathol. 71, 540-543.

Petzoldt, C.H., Sall, M.A. \& Moller, W.J., 1983. Factors determining the relative number of ascospores released by Eutypa armeniacae in California. Plant Dis. $67,857-860$.

Ramsdell, D.C., 1995. Winter air-blast sprayer applications of benomyl for reduction of Eutypa dieback disease incidence in concorde grape vineyard in Michigan. Plant Dis. 79, 399-402.

Rolshausen, P.E. \& Gubler, W.D., 2005. Use of boron for the control of Eutypa dieback of grapevines. Plant Dis. 89, 734-738.

SAS, 1990. SAS/STAT User's Guide, Version 6, Fourth Edition, Volume 2. SAS Institute Inc, SAS Campus Drive, Cary, NC 27513.

Schmidt, C.S., Lorenz, D., Wolf, G.A. \& Jäger, J., 2001. Biological control of the grapevine dieback fungus Eutypa lata II: Influence of formulation additives and transposon mutagenesis on the antagonistic activity of Bacillus subtilis and Erwinia herbicola. J. Phytopathol. 149, 437-445.

Shapiro, S.S. \& Wilk, M.B., 1965. An analysis of variance test for normality (complete samples). Biometrika 52, 591-611.

Sosnowski, M.R., Creaser, M.L. \& Wicks, T.J., 2004. Evaluating fungicides as pruning wound treatments to control eutypa dieback. The Aust. New Zealand Grapegrower and Winemaker. Ann. Tech. Issue 485a, 51-53.

Sosnowski, M.R., Creaser, M.L., Wicks, T.J., Lardner, R. \& Scott, E.S., 2008. Protection of grapevine pruning wounds from infection by Eutypa lata. Aust. J. Grape Wine Res. 14, 134-142.

Trese, A.T., Burton, C.L. \& Ramsdell, D.C., 1980. Eutypa armeniacae in Michigan vineyards: ascospore production and survival, host infection, and fungal growth at low temperatures. Phytopathol. 70, 788-793.

Trese, A.T., Ramsdell, D.C. \& Burton, C.L., 1982. Effects of winter and spring pruning and postinoculation cold weather on infection of grapevine by Eutypa armeniacae. Phytopathol. 72, 438-440.

Van Niekerk, J., Fourie, P.H. \& Halleen, F., 2003. Ekonomiese impak van Eutypa terugsterwing van wingerd. Wynboer 173, 10-12.

Van Niekerk, J.M., 2008. Epidemiology of grapevine trunk disease pathogens. $\mathrm{PhD}$ dissertation, University of Stellenbosch, Private Bag X1, 7602 Matieland (Stellenbosch), South Africa.

Wicks, T. \& Davies, K., 1999. The effect of Eutypa on grapevine yield. The Aust. Grapegrower and Winemaker. Ann. Tech. Issue 426a, 15-16. 